\title{
CHARACTERIZATION OF Acromyrmex subterraneus brunneus (HYMENOPTERA: FORMICIDAE) YOUNG NESTS IN AFRAGMENT OF THE NEOTROPICAL FOREST $^{1}$
}

\author{
Roberto da Silva Camargo ${ }^{2}$, Luiz Carlos Forti² ${ }^{2}$ Juliane Floriano Lopes ${ }^{3}$ and Ana Paula Protti de Andrade ${ }^{2}$
}

\begin{abstract}
Young nests of Acromyrmex subterraneus brunneus are characterized by refuse soil in the exterior of the nest, a single fungus chamber 11 to $20 \mathrm{~cm}$ deep in relation to soil surface and internal volume ranging from 0.3 to 1.5 liters. These nidification patterns are important characteristics for identifying and understanding the interactions between species and their habitats.
\end{abstract}

Key words: Acromyrmex subterraneus brunneus, leaf-cutting ants, nest and fungus chamber.

\section{CARACTERIZAÇÃO DE NINHOS JOVENS DE Acromyrmex subterraneus brunneus (HYMENOPTERA: FORMICIDAE) EM FRAGMENTO DE FLORESTA NEOTROPICAL}

\begin{abstract}
RESUMO - Ninhos jovens de Acromyrmex subterraneus brunneus caracterizam-se pela terra solta no exterior do ninho, por ter uma única câmara de fungo com profundidade de 11 a $20 \mathrm{~cm}$ em relação à superfície do solo e por ter volume interno variando de 0,3 a 1,5 litros. Estes padrões de nidificação são caracteres importantes para a identificação e o conhecimento das interações da espécie com o seu habitat.
\end{abstract}

Palavras-chave: Acromyrmex subterraneus brunneus, formigas cortadeiras, ninho e câmara de fungo.

In the Neotropics, ants of the genera Atta and Acromyrmex are capable of consuming a larger amount of vegetation than any other local herbivore (Hölldobler \& Wilson, 1990). These plants are used for symbiotic fungus cultivation of Leucoagaricus gongylophorus (Fisher et al., 1994), the main food source for larvae in colonies (Weber, 1972; Bass \& Cherrett, 1995).

The notable social structures combined with the elaborate architecture of nests promote efficient nutrient cycling, essential for forest equilibrium (Haines, 1983). However, the internal nest architecture of many leaf-cutting ant species is still unknown, especially the characterization of nests in the initial phase of development. Thus, the objective of this paper is to describe and characterize young nests of Acromyrmex subterraneus brunneus Forel, 1911.

The study was carried out in a mesophyll semideciduous forest fragment in Piracicaba, São Paulo, Brazil. Ten nests of $A$. s. brunneus, approximately 1 year old, were excavated with the aim of studying the following characteristics: length (l), width (w), internal depth of fungus chamber (id) and depth of fungus chamber in relation to soil surface (Table 1). These data were used to calculate the internal volume of the fungus chamber, through the sphere formula, $\mathrm{V}=\mathrm{p} / 6$.l.w.id (Moreira \& Forti, 1999). For photographic documentation, chambers were dusted with neutral talc with manual dust equipment.

1 Recebido para publicação em 19.3.2003 e aceito para publicação em 30.4.2004.

2 Dep. de Produção Vegetal da Faculdade de Ciências Agronômicas, Universidade Estadual Paulista - UNESP, Caixa Postal 237, 18603-970 Botucatu-SP, Brasil, <luizforti@fca.unesp.br>; ${ }^{3}$ Dep. de Zoologia, Instituto de Biociências, UNESP, 18618-000 Botucatu-SP, Brasil. 
The nests of A. s. brunneus were observed to be totally subterranean with refuse soil in the exterior and the absence of straw as covering. Adult nests may generally be covered by a conical hill of straw formed from pieces of dry leaves and interlaced wood chips (Gonçalves, 1961; Delabie, 1989) or without covering (Andrade \& Forti, 1999).

Most nests of A. s. brunneus presented a volume smaller than 0.60 liters, although nests with more than 1.5 liters of volume may be found (Figure 1). The fungus chambers were found with depths ranging from $11 \mathrm{~cm}$ up to $20 \mathrm{~cm}$ in relation to the soil surface (Table 1), similar to the young nests of Atta spp. (Autuori, 1949; Pereira-daSilva, 1975). Differentiated chambers for the depositing of refuse material were not encountered (Figure 2).
A large quantity of roots was found inside the fungus chamber, promoting symbiotic fungus culture (Figure 2). Specifics regarding the interaction between the roots of the plants and leaf-cutting ants remain largely unknown.

During excavation, a great number of arthropods associated with the nests were observed, such as collembolans and spiders (personal observation), showing their importance in maintaining biodiversity and also the dilution and genesis of soils in this fragment of Neotropical forest.

Furthermore, nests are of extreme importance for many animals because they facilitate procreation and food storage, as well as protection against natural enemies

Table 1 - Dimensions of chambers in Acromyrmex subterraneus brunneus nests ( $\mathrm{N}=10)$, Piracicaba, São Paulo, 2002

Quadro 1 - Dimensões das câmaras em ninhos $(N=10)$ de Acromyrmex subterraneus brunneus, Piracicaba, São Paulo, 2002

\begin{tabular}{|l|c|c|c|c|c|}
\hline \multicolumn{1}{|c|}{$\begin{array}{c}\text { Dimensions } \\
(\mathrm{cm})\end{array}$} & Mode & Mean & $\begin{array}{c}\text { Standard } \\
\text { Deviation }\end{array}$ & Maximum & Minimum \\
\hline Length & 10 & 10.1 & 1.87 & 13 & 8 \\
\hline Width & 9 & 8.9 & 1.76 & 13 & 7 \\
\hline Internal depth & 10 & 10,0 & 2.45 & 17 & 8 \\
\hline Depth of fungus chamber in relation to soil surface & 12 & 13.4 & 2.91 & 20 & 11 \\
\hline
\end{tabular}

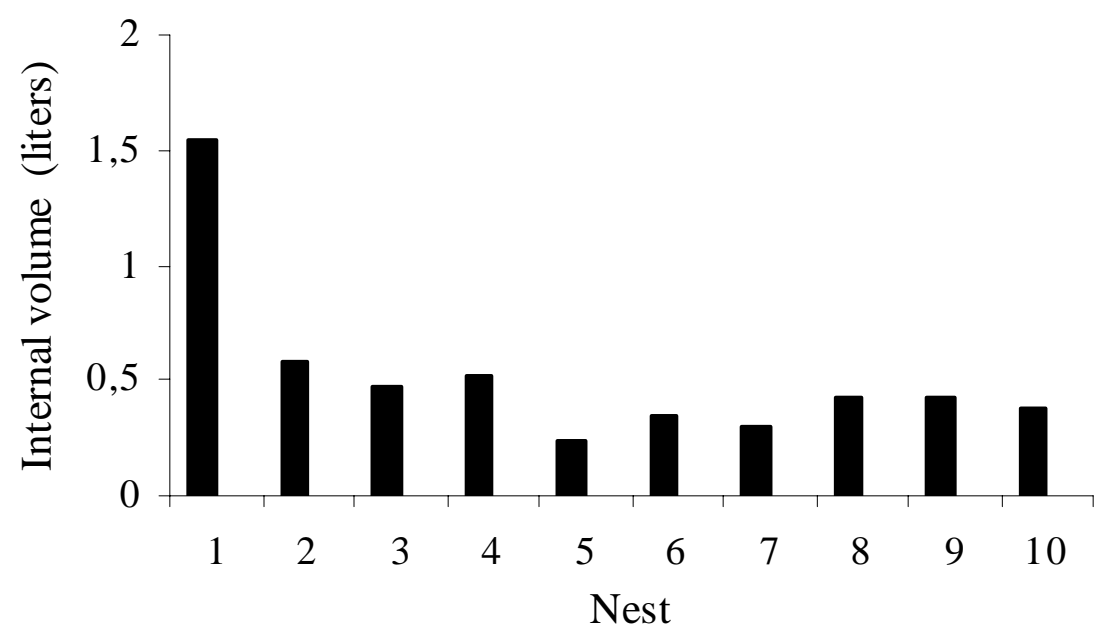

Figure 1 - Volume (liters) estiimated by geometric forms of a sphere, of the fungus chamber of Acromyrmex subterraneus brunneus nests. Piracicaba, São Paulo, 2002.

Figura 1 - Volume estimado (litros) por formas geométricas da esfera, da camâra de fungo dos ninhos de Acromyrmex subterraneus brunneus. Piracicaba, São Paulo, 2002.

R. Árvore, Viçosa-MG, v.28, n.2, p.309-312, 2004 

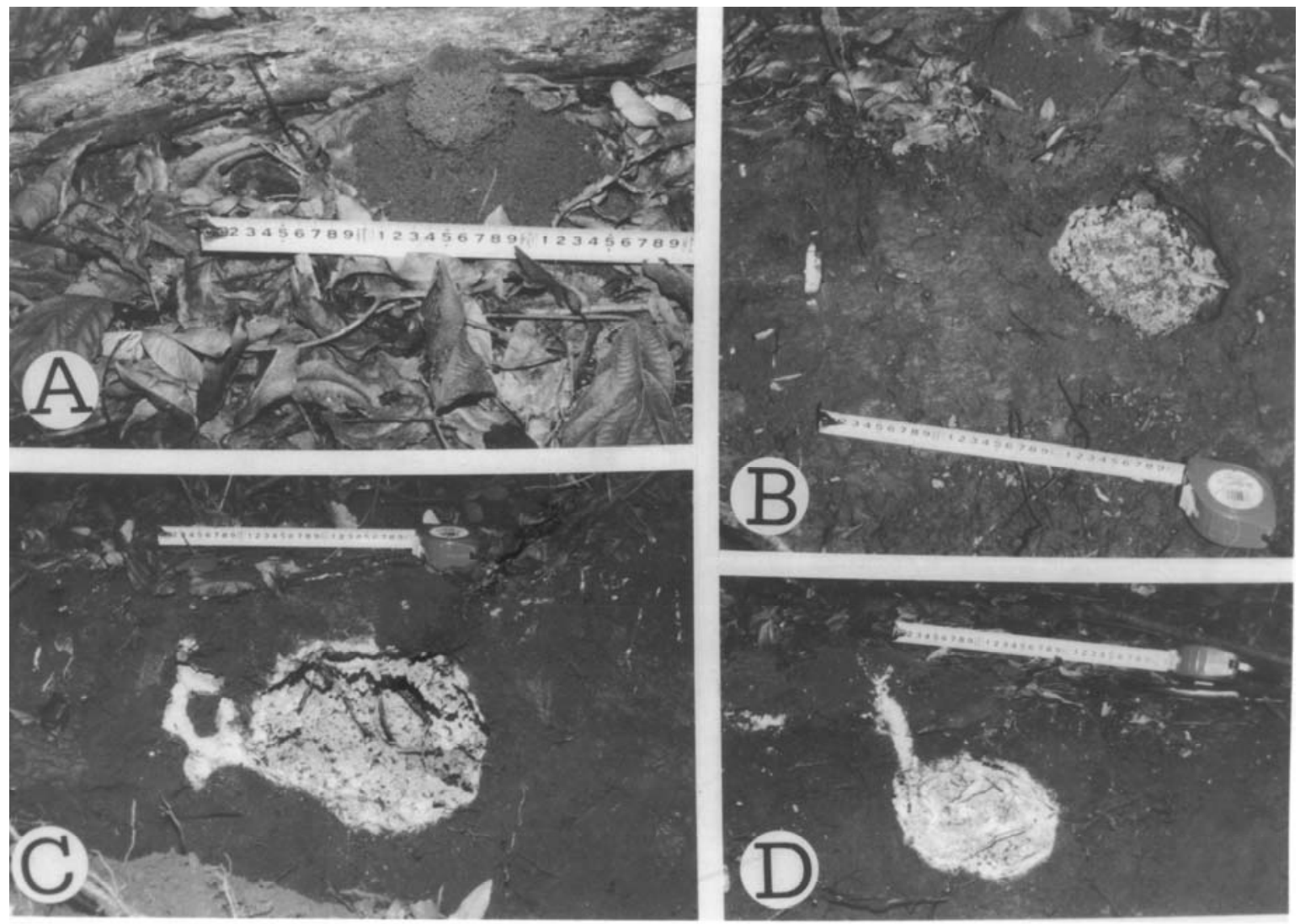

Figure 2 - Young nests of Acromyrmex subterraneus brunneus: (A) external aspect of nest, soil refuse; (B and D) details of fungus chamber excavated; (C) symbiotic fungus. Piracicaba, São Paulo, 2002.

Figura 2 - Ninhos jovens de Acromyrmex subterraneus brunneus: (A) aspecto externo do ninho, terra solta; (B e D) detalhe da câmara de fungo escavada; (C) fungo simbionte. Piracicaba, São Paulo, 2002.

and weather. These functions promote nidification patterns that are adjusted to the needs of each species.

Thus, the knowledge of nest architecture contributes to the establishment of species nidification patterns. These characteristics are fundamental to identify and understand the interactions of various species with their habitats.

\section{ACKNOWLEDGMENTS}

We wish to thank Fundação de Amparo à Pesquisa do Estado de São Paulo (FAPESP) for a fellowship granted to the senior author (grants 01/11895-1 and 02/02011-5). L. C. Forti gratefully acknowledges the support of the Conselho Nacional de Desenvolvimento Científico e Tecnológico (CNPq) of Brazil (grant: 306 504/88-0). We thank Mr. James R. Welsh for the English revision of the text.

\section{REFERENCES}

ANDRADE, A. P. P.; FORTI, L. C. Arquitetura dos ninhos de Acromyrmex subterraneus brunneus, Forel (Hymenoptera: Formicidae). Naturalia, v. 24, p. 33-35, 1999.

AURUORI, M. Investigações sobre a biologia da saúva. Ciência e Cultura, v. 1, p. 1-12, 1949.

BASS, M.; CHERRETT, J. M. Fungal hyphae as a source of nutrients for the leaf-cutting ant Atta sexdens.

Physiological Entomology, v. 20, p. 1-6, 1995. 
DELABIE, J. C. H. Observações sobre a ocorrência de poliginia em colônias de Acromyrmex subterraneus brunneus Forel, 1893, em cacauais (Formicidae, Myrmicinae, Attini).

Anais da Sociedade Entomológica do Brasil, v. 18, p. 193-197, 1989.

FISHER, P. J.; STRADLING, D. J.; PEGLER, D. N. Leaf cutting ants, their fungus gardens and the formation of basidiomata of Leucoagaricus gongylophorus. Mycologist, v. 8, p. 128-132, 1994.

GONÇALVES, C. R. O gênero Acromyrmex no Brasil (Hymenoptera, Formicidae). Studia Entomologica, v. 4, p. 113-180, 1961.

HAINES, B. Leaf-cutting ants bleed mineral elements out of rainforest in southern Venezuela. Tropical Ecology, v. 24, p. 86-93, 1983.
HÖLLDOBLER, B.; WILSON, E. O. The ants. Cambridge: Harvard University Press, 1990. 732 p.

MOREIRA, A. A.; FORTI, L. C. Comparação entre o volume externo e interno de ninhos de Atta laevigata (Hymenoptera: Formicidae). Revista Árvore, v. 23, p. 355-358, 1999.

PEREIRA-DA-SILVA, V. Contribuição ao estudo das populações de Atta sexdens rubropilosa Forel, e Atta laevigata (Fr. Smith) no estado de São Paulo (Hym.: Formicidae). Studia Entomologica, v. 18, p. 201-250, 1975.

WEBER, N. A. Gardening ants: the Attines. Philadelphia: Memoirs of the American Philosophical Society, 1972. $146 \mathrm{p}$. 